\title{
Prevalence, Risk Factors, and Outcomes of Platelet Transfusion Refractoriness in Critically Ill Patients: A Retrospective Cohort Study
}

\author{
Saeed Arabi, ${ }^{1,2}$ Abdullah O. Almahayni, ${ }^{1,2}$ Abdulrahman A. Alomair,, \\ Emad M. Masuadi $\mathbb{D}^{1,2}$ Moussab Damlaj $\mathbb{D}^{1,1,2,3}$ and Hasan M. Al-Dorzi ${ }^{10}{ }^{1,2,4}$ \\ ${ }^{1}$ College of Medicine, King Saud bin Abdulaziz University for Health Sciences, Riyadh, Saudi Arabia \\ ${ }^{2}$ King Abdullah International Medical Research Center, Riyadh, Saudi Arabia \\ ${ }^{3}$ Department of Oncology, King Abdulaziz Medical City-Riyadh, Ministry of National Guard Health Affairs, \\ Riyadh, Saudi Arabia \\ ${ }^{4}$ Intensive Care Department, King Abdulaziz Medical City-Riyadh, Ministry of National Guard Health Affairs, \\ Riyadh, Saudi Arabia \\ Correspondence should be addressed to Hasan M. Al-Dorzi; aldorzih@yahoo.com
}

Received 8 February 2021; Revised 3 August 2021; Accepted 3 September 2021; Published 24 September 2021

Academic Editor: Samuel A. Tisherman

Copyright (C) 2021 Saeed Arabi et al. This is an open access article distributed under the Creative Commons Attribution License, which permits unrestricted use, distribution, and reproduction in any medium, provided the original work is properly cited.

\begin{abstract}
Background. Refractoriness to platelet transfusion is an understudied phenomenon in critically ill patients. Our objective was to evaluate the prevalence, risk factors, and clinical outcomes of platelet refractoriness among patients in a tertiary-care intensive care unit (ICU). Methods. A retrospective cohort study included all patients (age $>14$ years) who were admitted to a tertiary-care medical-surgical ICU between 2011 and 2016 and received $\geq 2$ platelet transfusions during their ICU stay. We calculated platelet increment (PI) and corrected count increment (CCI). Results. A total of 267 patients were enrolled in the study, collectively receiving 1357 transfusions with a median of 4.0 (interquartile range: 2.0,6.0) transfusions per patient. The median pretransfusion platelet count was $31000.0 \times 10^{6} / \mathrm{L}$ (interquartile range: $16000.0,50000.0$ ). The median PI was $6000 \times 10^{6} / \mathrm{L}$. The prevalence of platelet transfusion refractoriness was $54.8 \%$ based on PI $<10000 \times 10^{6} / \mathrm{L}$ and $57.0 \%$ based on CCI $<5000$. Patients admitted under hepatology/liver transplant had the highest rates of platelet refractoriness (69.6\%), while those under general surgery had the lowest rate (43.2\%). Younger age, nontrauma admission, and larger spleen size were associated with platelet refractoriness. Finally, refractoriness was associated with increased length of stay in the ICU $(p=0.02)$, but not with mortality. Conclusions. Platelet transfusion refractoriness was highly $(>50 \%)$ prevalent in ICU patients. However, it was not associated with increased mortality.
\end{abstract}

\section{Introduction}

Thrombocytopenia is commonly seen in critically ill patients. Its incidence and prevalence during intensive care unit (ICU) admission have been reported to be $13-44.1 \%$ and $8.3-67.6 \%$, respectively [1]. The variability in epidemiology reflects heterogeneity in patient characteristics and differing thrombocytopenia thresholds [1]. Thrombocytopenia is associated with increased mortality, prolonged ICU and hospital stay, and bleeding, as well as blood product consumption [1,2]. Prophylactic and therapeutic platelet transfusion is a common practice in the ICU; however, patients may experience platelet transfusion refractoriness, a phenomenon in which the expected posttransfusion platelet count increment is not achieved.

Platelet transfusion refractoriness is predominantly reported in patients with hematologic disorders [3], and its prevalence varies among studies from 4.8 to $49.6 \%$ (Table 1) [4-11]. The prevalence was $34 \%$ in severe aplastic anemia patients [12], 27.6\% in patients receiving multiple platelet transfusions [4], and $10 \%$ in patients with acute myeloid leukemia receiving induction chemotherapy [5]. Causes can be immune and nonimmune. Immune-mediated refractoriness is mainly due to alloimmunization to human platelet 
TABLE 1: Selected studies evaluating prevalence and outcomes of platelet refractoriness.

\begin{tabular}{|c|c|c|c|c|c|}
\hline Study & Type & Population & Method & Prevalence & Clinical outcomes \\
\hline $\begin{array}{l}\text { Legler et al., } \\
1997[4]\end{array}$ & $\begin{array}{l}\text { Prospective } \\
\text { cohort }\end{array}$ & $\begin{array}{l}145 \text { patients with hemato- } \\
\text { oncological disease at a } \\
\text { single center, who received } \\
\text { at least two platelet } \\
\text { transfusions }\end{array}$ & $\begin{array}{c}\text { Platelet counts repeatedly after } \\
\geq \text { two successive platelet } \\
\text { transfusions within } 48 \\
\text { hours }<20000 \times 10^{6} / \mathrm{L}(16-\mathrm{hr} \\
\text { count }) \text { or }<10000 \times 10^{6} / \mathrm{L}(24-\mathrm{hr} \\
\text { count })\end{array}$ & $27.6 \%$ & Not assessed \\
\hline $\begin{array}{l}\text { TRAP } \\
\text { study, } 1997 \\
{[5]}\end{array}$ & $\begin{array}{l}\text { Randomized } \\
\text { clinical trial }\end{array}$ & $\begin{array}{l}530 \text { patients receiving } \\
\text { induction chemotherapy } \\
\text { for acute myeloid leukemia }\end{array}$ & $\begin{array}{c}\text { CCI }<5000 \text { after two sequential } \\
\text { transfusions }\end{array}$ & $10 \%$ & $\begin{array}{l}\text { No comparison between } \\
\text { refractory and } \\
\text { nonrefractory patients } \\
\text { reported }\end{array}$ \\
\hline $\begin{array}{l}\text { Meehan } \\
\text { et al., } 2000 \\
{[6]}\end{array}$ & $\begin{array}{l}\text { Prospective } \\
\text { cohort }\end{array}$ & $\begin{array}{l}292 \text { consecutive patients at } \\
\text { a single hospital who } \\
\text { received platelet } \\
\text { transfusions over a six- } \\
\text { month period }\end{array}$ & $\begin{array}{l}\text { Three consecutive days of platelet } \\
\text { transfusions produced } \\
\text { posttransfusion platelet count } \\
\text { increments (corrected or } \\
\text { uncorrected) } \leq 5000 \times 10^{6} / \mathrm{L}\end{array}$ & $21.6 \%$ & $\begin{array}{c}\text { Among refractory patients } \\
\text { (compared to } \\
\text { nonrefractory) } \\
\text { (i) Increased mean platelet } \\
\text { use (units): } 20.6 \text { vs. } 2.8, \\
p<0.0001 \\
\text { (ii) Increased mean } \\
\text { hospitalization costs (US } \\
\$ \text { ): } 103,956 \text { vs. } 36,818, \\
p<0.0001 \\
\text { (iii) Increased mean length } \\
\text { of stay: } 35.0 \text { vs. } 14.4 \text { days, } \\
p<0.0001\end{array}$ \\
\hline $\begin{array}{l}\text { Slichter } \\
\text { et al., } 2005 \\
{[7]}\end{array}$ & $\begin{array}{l}\text { Ad hoc analysis of } \\
\text { a randomized } \\
\text { clinical trial }\end{array}$ & $\begin{array}{l}533 \text { patients receiving } \\
\text { induction chemotherapy } \\
\text { for acute myeloid leukemia }\end{array}$ & $\begin{array}{c}2 \text { sequential } 1 \text {-hour } \\
\text { posttransfusion platelet } \\
\text { increments of less than } \\
\quad 11000 \times 10^{6} / \mathrm{L}\end{array}$ & $27 \%$ & Not assessed \\
\hline $\begin{array}{l}\text { Kerkhoffs } \\
\text { et al., } 2008 \\
\text { [8] }\end{array}$ & $\begin{array}{l}\text { Ad hoc analysis of } \\
\text { a randomized } \\
\text { clinical trial }\end{array}$ & $\begin{array}{l}117 \text { patients hospitalized in } \\
\text { the hematology ward who } \\
\text { needed or were expected to } \\
\text { need } 2 \text { or more platelet } \\
\text { transfusions }\end{array}$ & $\begin{array}{c}\text { 1-hour CCI }<7500 \text { and/or a } 24- \\
\text { hour CCI }<4500\end{array}$ & $49.6 \%$ & $\begin{array}{c}\text { Among refractory } \\
\text { (compared to } \\
\text { nonrefractory patients) } \\
\text { (i) Decreased 100-day } \\
\text { survival (83\% vs. 98\%, } \\
p<0.01 \text { ) } \\
\text { (ii) Decreased median } \\
\text { survival (491.0 days (Q1, } \\
\text { Q3: } 156.0,858.0 \text { ) vs. } 825 \\
\text { days (Q1, Q3: } 355.0, \\
\text { 996.0), } p=0.032 \text { ) } \\
\text { (iii) Increased risk of } \\
\text { bleeding: odds ratio: } 3.4 \text {; } \\
\text { 95\% CI: } 1.1-11\end{array}$ \\
\hline $\begin{array}{l}\text { Ferreira } \\
\text { et al., } 2011 \\
\text { [9] }\end{array}$ & $\begin{array}{l}\text { Prospective } \\
\text { cohort }\end{array}$ & $\begin{array}{l}16 \text { adult oncology/ } \\
\text { hematology patients }\end{array}$ & $\begin{array}{l}\text { Two successive transfusions with } \\
\qquad \text { CCI }<5000\end{array}$ & $\begin{array}{c}19 \%(3 \\
\text { patients })\end{array}$ & Not assessed \\
\hline $\begin{array}{l}\text { Hess et al., } \\
2016[10]\end{array}$ & $\begin{array}{l}\text { Secondary } \\
\text { analysis of a } \\
\text { randomized } \\
\text { clinical trial }\end{array}$ & $\begin{array}{l}734 \text { hematology-oncology } \\
\text { patients receiving at least } 2 \\
\text { platelet transfusions }\end{array}$ & Two consecutive CCIs of $\leq 5000$ & $14 \%$ & Not assessed \\
\hline
\end{tabular}


TABLE 1: Continued.

\begin{tabular}{|c|c|c|c|c|c|}
\hline Study & Type & Population & Method & Prevalence & Clinical outcomes \\
\hline $\begin{array}{l}\text { Comont } \\
\text { et al., } 2017 \\
{[11]}\end{array}$ & $\begin{array}{c}\text { Retrospective } \\
\text { cohort }\end{array}$ & $\begin{array}{l}897 \text { adult patients with } \\
\text { acute myeloid leukemia } \\
\text { receiving intensive } \\
\text { chemotherapy }\end{array}$ & $\begin{array}{l}\text { Persistent thrombocytopenia } \\
<10000 \times 10^{6} / \mathrm{L} \text { despite at least } \\
\text { two successive daily platelet } \\
\text { transfusions }\end{array}$ & $4.8 \%$ & $\begin{array}{l}\text { Among patient with } \\
\text { refractoriness (compared } \\
\text { to those without) } \\
\text { (i) Increased severe } \\
\text { bleeding events }(22 \% \text { vs. } \\
4.1 \%, p<0.0001) \\
\text { (ii) Increased early death } \\
\text { caused by bleeding }(12.2 \% \\
\text { vs. } 1.4 \%, p=0.0006) \\
\text { (iii) Increased death by } \\
\text { bleeding at any time } \\
\text { ( } 24.4 \% \text { vs. } 5.3 \%, \\
p<0.0001)\end{array}$ \\
\hline
\end{tabular}

CCI: corrected count increment, CI: confidence interval, Q1: first quartile, Q3: third quartile.

antigens and human leukocyte antigens (anti-HLA antibodies), which is more common $[13,14]$. When associated with HLA alloimmunization, refractoriness causes increased platelet requirements and delayed bleeding [15]. However, anti-HLA antibodies account for less than $30 \%$ of total causes of refractoriness [4], and not all patients who get alloimmunized to HLA antigens develop refractoriness [13]. Strategies such as leukocyte reduction, UV-B irradiation, and use of apheresis platelets have reduced the incidence of immune-mediated platelet refractoriness [5], making nonimmune etiologies, such as ABO-incompatibility, transfusion of old platelets, sepsis, disseminated intravascular coagulation (DIC), splenomegaly, bleeding, and medications, underlie most cases of platelet refractoriness $[7,8,13,16]$. Most of these factors are commonly seen in the ICU.

Irrespective of the underlying etiology, platelet transfusion refractoriness is a clinically important problem in the ICU. It has been associated with increased complications and mortality $[8,13]$. However, there is paucity of studies on the prevalence and clinical significance of platelet refractoriness in the ICU setting. Thus, the objectives of this study were to explore the prevalence, risk factors, and clinical outcomes of platelet transfusion refractoriness among patients admitted to the general ICU of a tertiary-care hospital.

\section{Materials and Methods}

2.1. Patients and Setting. This was a retrospective cohort study that was conducted in the adult noncardiac ICUs of King Abdulaziz Medical City, Riyadh, Saudi Arabia. The Institutional Review Board of the Ministry of National Guard Health Affairs approved this study. The hospital was a tertiary-care center in Riyadh, with a capacity of $>1000$ beds treating a variety of medical conditions and specialties including hematology, oncology, and hematopoietic stem cell transplantation. The ICUs collectively had 60 beds servicing medical, surgical, and trauma patients. Multidisciplinary consultant-based teams provided care with in-house on-call physicians 24 hours per day, 7 days per week [17]. Platelets were transfused at the discretion of the treating ICU team as no related protocol existed during the study period.
Typically, the prophylactic transfusion threshold was platelet count $<10000-20000 \times 10^{6} / \mathrm{L}$ and therapeutic threshold $<50000 \times 10^{6} / \mathrm{L}$ in the presence of active bleeding or when an invasive procedure was required. In our institution, six units of single donor platelets prepared from whole blood were pooled to produce a single pooled platelet concentrate; apheresis platelets were given upon a specific request from the treating ICU team; otherwise, pooled platelets were given; irradiated platelets were dispatched preferentially to hematology/hematopoietic stem cell transplantation patients where available, and all units of platelets were leukocyte reduced. Each platelet transfusion episode usually consisted of a single concentrate. The time interval between a platelet transfusion episode and the posttransfusion platelet count was determined by the treating ICU team and depended on the clinical condition of the patient.

The study patients included all adults ( $\geq 14$ years old) admitted to the ICU between 2011 and 2016 and received at least two platelet transfusions during the ICU admission. For patients with more than one ICU admission within the same hospitalization, only the first admission was considered.

2.2. Data Collection and Definitions. Data were collected from different sources, primarily the electronic medical records, ICU administrative database, and hospital blood bank database. Collected variables included patient demographics and clinical characteristics on admission (diagnosis, admission category, Glasgow Coma Scale (GCS), and Acute Physiologic Assessment and Chronic Health Evaluation (APACHE) II score). The date, time, platelet product type (pooled or apheresis), irradiation status, and number of units of each transfusion were noted. Platelet count on admission, nadir platelet count during ICU admission, and the platelet counts before and after each transfusion were recorded. When no platelet count could be found in between two or more platelet transfusions, those transfusions were added up and considered as one. When available, we measured the spleen size of each patient within 30 days of admission based on imaging studies in the hospital Picture Archiving and Communication System. Assessed outcomes were platelet transfusion refractoriness, the interval to next 
platelet transfusion, ICU and hospital length of stay, ICU and hospital mortality, duration of mechanical ventilation, and new tracheostomy insertion.

In this study, we defined refractoriness to platelet transfusions as a platelet increment $(\mathrm{PI})$ of $<10000 \times 10^{6} / \mathrm{L}$ on at least two consecutive occasions within the same ICU admission. PI was calculated by subtracting the pretransfusion from the posttransfusion platelet count. We also used a definition based on the corrected count increment (CCI) for comparison [3]. CCI adjusts the PI for the amount of platelets transfused and for body surface area and is calculated using the following formula [8]:

$$
\mathrm{CCI}=\frac{\text { platelet increment } \times \text { body surface area }}{\text { absolute number of transfused platelets }} .
$$

The absolute number of platelets was estimated at $3.0 \times 10^{11}$ for each unit of apheresis platelets and $3.3 \times 10^{11}$ for each pooled platelet concentrate [18]. Body surface area was calculated using the Mosteller formula as follows [19]:

$$
\text { Body surface area }=\sqrt{\frac{\text { weight }(\mathrm{kg}) \times \text { height }(\mathrm{cm})}{3600}} \text {. }
$$

Patients with CCI $<5000$ on at least two consecutive occasions were considered refractory to platelet transfusion $[5,9,10]$. Splenomegaly was defined as a splenic craniocaudal diameter of $>13 \mathrm{~cm}$ on an abdominal CT scan or an abdominal ultrasound [20]. Thrombocytopenia was defined as platelet count $<150000 \times 10^{6} / \mathrm{L}$ [21]. DIC was recorded as a likelihood score adapted from the sepsis-induced coagulopathy score, where a higher score indicated a higher likelihood of DIC [22].

2.3. Statistical Analysis. Platelet transfusion refractoriness was analyzed using a "wide" data format, where each row represented a different patient and each different data variable was put in a separate column. The PI and CCI for each transfusion episode, time interval to posttransfusion platelet count, and time interval to the next transfusion, which represented time points per patient, were analyzed using a "long" data format, where each row represented a single transfusion and variables that do not change across time had the same value in all the rows. The patient cohort was stratified according to platelet transfusion refractoriness. The time interval to the next transfusion was categorized into two groups: group 1: $<48$ hours and group 2: $\geq 48$ hours. The 48 -hour limit was chosen as it would clinically indicate the requirement for earlier platelet transfusion and because other studies showed that the average time to next transfusion was close to 48 hours [7]. Continuous variables were presented as medians with the first and third quartiles (Q1 and Q3). Categorical variables were presented as frequencies with percentages. The characteristics and outcomes of the different groups were compared using a rank-based nonparametric test (continuous or ordinal data) or the chi-square test (categorical data), as appropriate. The diagnosis of platelet transfusion refractoriness by PI was compared against that by CCI using kappa statistics, sensitivity, and specificity. The relationship between the time interval to the next transfusion and each of PI and CCI was assessed using Spearman correlation (skewed distribution of data).

A binary logistic regression model was used to identify predictors of platelet transfusion refractoriness. Variables with $p$ values $<0.25$ on univariate analysis were entered in the model [23] in addition to clinically relevant variables. The independent variables entered in the model were age, APACHE II score, admission category, hematologic malignancy, chronic liver disease, sepsis, shock, the first pretransfusion platelet count, spleen size, DIC likelihood score, and the platelet product type (apheresis, apheresis-irradiated, pooled, pooled-irradiated, and mixed) on the first and second transfusion episodes. The results were reported as odds ratio (OR) and 95\% confidence interval (CI). Data were analyzed using SPSS v 25. $p$ values $<0.05$ were considered statistically significant.

\section{Results}

3.1. Patients and Transfusion Characteristics. Between 2011 and 2016, 259 patients required platelet transfusion on $\geq 2$ occasions and were included in the study, collectively receiving 1357 platelet transfusions. The characteristics of the study patients are summarized in Table 2 . The median age was 58 years (Q1, Q3: 43.5, 70.0), most (57.5\%) patients were males, and $84.9 \%$ were admitted for a medical reason. About a third (35.5\%) had cancer, almost two-thirds (63.3\%) were in shock on ICU admission, 59.8\% were septic, and $20.1 \%$ had a form of bleeding.

The majority $(87.6 \%)$ of the patients had thrombocytopenia (platelet count $<150000 \times 10^{6} / \mathrm{L}$ ) on admission with count $<50000 \times 10^{6} / \mathrm{L}$ present in $45.7 \%$. The rest $(12.4 \%)$ developed thrombocytopenia during their ICU stay. The median platelet count on admission was $53500.0 \times 10^{6} / \mathrm{L}$ (Q1, Q3: 28000.0, 98800.0). The median platelet nadir was $18000.0 \times 10^{6} / \mathrm{L}$ (Q1, Q3: 10000.0, 29000.0). Each patient received platelet transfusion on a median of 4.0 (Q1, Q3: 2.0, 6.0) occasions. The median number of platelet concentrates per each transfusion episode was 1.0 (Q1, Q3: 1.0, 2.0). Most of the transfused platelets were pooled unirradiated (55.3\%), while pooled-irradiated platelets accounted for $13.4 \%$, apheresis platelets accounted for $10.2 \%$, and apheresis-irradiated platelets accounted for $14.4 \%$.

The median time interval to next transfusion was 1.0 day (Q1, Q3: 1.0, 2.0). The posttransfusion platelet count was taken a median of 5.0 hours (Q1, Q3: 2.9, 7.6; range: 0, 40.0 hours) after transfusion.

\subsection{Platelet Increment and Platelet Transfusion Refractoriness.} The median PI was $6000.0 \times 10^{6} / \mathrm{L}$ (Q1, Q3: -5000.0 , 24000.0), and the median CCI was 2800.0 (Q1, Q3: -2000.0, 10800.0). Figure 1 describes the platelet count before and after platelet transfusion in patient subgroups, categorized by the admitting service and by the transfused platelet product type (apheresis, apheresis-irradiated, pooled, pooled-irradiated, and mixed). The PI was statistically 
TABLE 2: General characteristics of patients by platelet transfusion refractoriness status based on the platelet increment $\left(<10000 \times 10^{6} / \mathrm{L}\right)$ definition.

\begin{tabular}{|c|c|c|c|c|c|}
\hline A. Patient characteristics & & Total $(N=259)$ & $\begin{array}{l}\text { Refractory } \\
(N=142)\end{array}$ & $\begin{array}{l}\text { Nonrefractory } \\
(N=117)\end{array}$ & $p$ value \\
\hline Age (years) & $\begin{array}{l}\text { Median (Q1, } \\
\text { Q3) }\end{array}$ & $58.0(43.5,70.0)$ & $57.0(42.2,68.0)$ & $60.0(46.0,72.0)$ & 0.11 \\
\hline Male sex & $N(\%)$ & $149(57.5)$ & $81(57.0)$ & $68(58.1)$ & 0.86 \\
\hline Body mass index $\left(\mathrm{kg} / \mathrm{m}^{2}\right)$ & $\begin{array}{l}\text { Median (Q1, } \\
\text { Q3) }\end{array}$ & $27.3(22.4,32.3)$ & $27.9(22.3,32.9)$ & $26.6(22.6,31.4)$ & 0.40 \\
\hline Obese $>30 \mathrm{~kg} / \mathrm{m}^{2}$ & $N(\%)$ & $94(37.5)$ & $54(39.4)$ & $40(35.1)$ & 0.60 \\
\hline Body surface area $\left(\mathrm{m}^{2}\right)$ & $\begin{array}{l}\text { Median (Q1, } \\
\text { Q3) }\end{array}$ & $1.8(1.6,1.9)$ & $1.8(1.7,1.9)$ & $1.8(1.6,1.9)$ & 0.42 \\
\hline Admission category & $N(\%)$ & & & & \\
\hline Medical & & $220(84.9)$ & $125(88.0)$ & $95(81.2)$ & 0.03 \\
\hline Surgical & & $30(11.6)$ & $16(11.3)$ & $14(12.0)$ & \\
\hline Trauma & & $9(3.5)$ & $1(0.7)$ & $8(6.8)$ & \\
\hline Chronic cardiac disease/238 patients* & $N(\%)$ & $35(15.2)$ & $18(13.6)$ & $17(17.3)$ & 0.44 \\
\hline Chronic immune disease/238 patients* & $N(\%)$ & $89(38.7)$ & $47(35.6)$ & $42(42.9)$ & 0.26 \\
\hline Chronic liver disease/238 patients* & $N(\%)$ & $48(20.9)$ & $35(26.5)$ & $13(13.3)$ & 0.01 \\
\hline Chronic respiratory disease/238 patients* & $N(\%)$ & $17(7.4)$ & $12(9.1)$ & $5(5.1)$ & 0.25 \\
\hline Chronic renal disease/238 patients* & $N(\%)$ & $29(12.6 \%)$ & $14(10.6 \%)$ & $15(15.3 \%)$ & 0.29 \\
\hline APACHE II score & $\begin{array}{l}\text { Median (Q1, } \\
\text { Q3) }\end{array}$ & $25.0(20.0,30.0)$ & $25.0(21.0,30.0)$ & $24.0(20.0,28.5)$ & 0.40 \\
\hline Glasgow Coma Scale on ICU admission & $\begin{array}{l}\text { Median }(\mathrm{Q} 1, \\
\text { Q3) }\end{array}$ & $14.0(9.5,15.0)$ & $14.0(9.0,15.0)$ & $14.0(10.0,15.0)$ & 0.97 \\
\hline Mechanical ventilation/238 patients* & $N(\%)$ & $191(83.0)$ & $110(83.3)$ & $81(82.7)$ & 0.89 \\
\hline $\mathrm{PaO}_{2} / \mathrm{FiO}_{2}$ ratio & $\begin{array}{l}\text { Median }(\mathrm{Q} 1 \text {, } \\
\text { Q3) }\end{array}$ & $178.5(113.2,270.5)$ & $176.0(112.2,258.0)$ & $182.0(114.0,282.5)$ & 0.38 \\
\hline Shock & $N(\%)$ & $164(63.3)$ & $91(64.1)$ & $73(62.4 \%)$ & 0.78 \\
\hline Sepsis & $N(\%)$ & $155(59.8 \%)$ & $88(62.0)$ & $67(57.3)$ & 0.44 \\
\hline Septic shock & $N(\%)$ & $149(57.5 \%)$ & $84(59.2)$ & $65(55.6)$ & 0.56 \\
\hline DIC likelihood score & $\begin{array}{l}\text { Median }(\mathrm{Q} 1, \\
\mathrm{Q} 3)\end{array}$ & $5.0(4.0,6.0)$ & $5.0(4.0,6.0)$ & $5.0(4.0,5.0)$ & 0.04 \\
\hline Active bleeding & $N(\%)$ & $52(20.1)$ & $27(19.0)$ & $25(21.4)$ & 0.64 \\
\hline Active cancer & $N(\%)$ & $92(35.5)$ & $47(33.1)$ & $45(38.5)$ & 0.37 \\
\hline Hematological cancer & $N(\%)$ & $75(29.0)$ & $38(26.8)$ & $37(31.6)$ & 0.39 \\
\hline Organ transplant & $N(\%)$ & $13(5.0)$ & $9(6.3 \%)$ & $4(3.4)$ & 0.28 \\
\hline Spleen size $(\mathrm{cm})$ & $\begin{array}{l}\text { Median (Q1, } \\
\text { Q3) }\end{array}$ & $11.5(9.4,14.0)$ & $12.5(10.5,14.4)$ & $10.7(8.9,13.2)$ & 0.001 \\
\hline \multicolumn{6}{|l|}{ Splenomegaly/178 patients* } \\
\hline Present & $N(\%)$ & $65(36.5)$ & $40(43.5)$ & $25(29.1)$ & 0.046 \\
\hline Absent & & $113(63.5)$ & $52(56.5)$ & $61(70.9)$ & \\
\hline Platelet count on ICU admission $\left(\times 10^{6} / \mathrm{L}\right)$ & $\begin{array}{l}\text { Median }(\mathrm{Q} 1, \\
\mathrm{Q} 3)\end{array}$ & $\begin{array}{l}53500.0(28000.0 \\
98800.0)\end{array}$ & $\begin{array}{l}49000.0(26000.0 \\
93000.0)\end{array}$ & $\begin{array}{l}59000.0(35000.0 \\
108000.0)\end{array}$ & 0.11 \\
\hline $\begin{array}{l}\text { Thrombocytopenia on admission } \\
\left(<150000 \times 10^{6} / \mathrm{L}\right)\end{array}$ & $N(\%)$ & $226(87.6 \%)$ & $123(87.2 \%)$ & $103(88.0 \%)$ & 0.85 \\
\hline $\begin{array}{l}\text { Severe thrombocytopenia on admission } \\
\left(<50000 \times 10^{6} / \mathrm{L}\right)\end{array}$ & $N(\%)$ & $118(45.7 \%)$ & $72(51.1 \%)$ & $46(39.3 \%)$ & 0.06 \\
\hline $\begin{array}{l}\text { Lowest platelet count during ICU stay }\left(\mathrm{x}^{1} 0^{9} /\right. \\
\mathrm{L})\end{array}$ & $\begin{array}{l}\text { Median }(\mathrm{Q} 1, \\
\mathrm{Q} 3)\end{array}$ & $18.0(10.0,29.0)$ & $14.0(7.0,28.0)$ & $19.0(11.0,34.0)$ & 0.001 \\
\hline s $15+5$ & Median (Q1, & $1.6(1.3,2.0)$ & $1.6(1.3,2.2)$ & $1.6(1.2,2.0)$ & 0.38 \\
\hline Lactic acid (mmol/L) & $\begin{array}{l}\text { Median }(\mathrm{Q} 1, \\
\mathrm{Q} 3)\end{array}$ & $2.9(1.7,6.0)$ & $2.9(1.5,5.9)$ & $3.0(1.8,6.1)$ & 0.47 \\
\hline Creatinine $(\mu \mathrm{mol} / \mathrm{L})$ & $\begin{array}{l}\text { Median }(\mathrm{Q} 1, \\
\text { Q3) }\end{array}$ & $142.5(73.8,256.2)$ & $145.0(82.2,260.2)$ & $134.5(65.8,232.0)$ & 0.33 \\
\hline Bilirubin $(\mu \mathrm{mol} / \mathrm{L})$ & $\begin{array}{l}\text { Median }(\mathrm{Q} 1, \\
\mathrm{Q} 3)\end{array}$ & $40.0(19.0,107.2)$ & $40.0(19.0,106.0)$ & $40.0(19.5,107.5)$ & 0.99 \\
\hline $\begin{array}{l}\text { Platelet transfusion refractoriness (CCI } \\
\text { definition) } / 256 \text { patients* }\end{array}$ & $N(\%)$ & $146(57.0 \%)$ & $139(98.6 \%)$ & $7(6.1 \%)$ & $<0.001$ \\
\hline B. Transfusion characteristics & & Total $(N=1357)$ & $\begin{array}{c}\text { Refractory } \\
(N=926)\end{array}$ & $\begin{array}{l}\text { Nonrefractory } \\
\quad(N=431)\end{array}$ & $\begin{array}{c}p \\
\text { value }\end{array}$ \\
\hline
\end{tabular}


TABle 2: Continued.

\begin{tabular}{|c|c|c|c|c|c|}
\hline \multicolumn{2}{|l|}{ A. Patient characteristics } & Total $(N=259)$ & $\begin{array}{l}\text { Refractory } \\
(N=142)\end{array}$ & $\begin{array}{l}\text { Nonrefractory } \\
\qquad(N=117)\end{array}$ & $p$ value \\
\hline \multicolumn{6}{|l|}{ Platelet product type } \\
\hline Apheresis & & $138(10.2 \%)$ & $98(10.6 \%)$ & $40(9.3 \%)$ & \\
\hline Apheresis-irradiated & & $196(14.4 \%)$ & $124(13.4 \%)$ & $72(16.7 \%)$ & \\
\hline Pooled & $N(\%)$ & $750(55.3 \%)$ & $508(54.9 \%)$ & $242(56.1 \%)$ & 0.06 \\
\hline Pooled-irradiated & & $182(13.4 \%)$ & $123(13.3 \%)$ & $59(13.7 \%)$ & \\
\hline Mixed $* * *$ & & $91(6.7 \%)$ & $73(7.9 \%)$ & $18(4.2 \%)$ & \\
\hline Platelet count prior to transfusion $\left(\times 10^{6} / \mathrm{L}\right)$ & $\begin{array}{l}\text { Median (Q1, } \\
\text { Q3) }\end{array}$ & $\begin{array}{c}31000.0(17000.0 \\
52000.0)\end{array}$ & $\begin{array}{c}31000.0(16000.0 \\
52000.0)\end{array}$ & $\begin{array}{c}33000.0(18000.0 \\
54000.0)\end{array}$ & 0.17 \\
\hline Number of transfusion episodes per patient & $\begin{array}{l}\text { Median }(\mathrm{Q} 1, \\
\text { Q3) }\end{array}$ & $4.0(2.0,6.0)$ & $5.0(3.0,8.0)$ & $3.0(2.0,4.0)$ & $<0.001$ \\
\hline $\begin{array}{l}\text { Number of platelet concentrates per } \\
\text { transfusion episode } * *\end{array}$ & Median (Q1, & $1.0(1.0,2.0)$ & $1.0(1.0,2.0)$ & $1.0(1.0,1.0)$ & $<0.001$ \\
\hline Time to next platelet transfusion (days) & $\begin{array}{l}\text { Median (Q1, } \\
\text { Q3) }\end{array}$ & $1.0(1.0,2.0)$ & $1.0(1.0,2.0)$ & $1.0(1.0,2.3)$ & 0.006 \\
\hline Platelet increment $\left(\mathrm{x}^{6} 0^{6} / \mathrm{L}\right)$ & $\begin{array}{l}\text { Median }(\mathrm{Q} 1, \\
\text { Q3) }\end{array}$ & $\begin{array}{l}6000.0(-5000.0 \\
24000.0)\end{array}$ & $\begin{array}{l}2000(-8000 \\
14000)\end{array}$ & $\begin{array}{l}21000.0(9000.0 \\
42000.0)\end{array}$ & $<0.001$ \\
\hline Corrected count increment $\left(\times 10^{6} / \mathrm{L}\right)$ & $\begin{array}{l}\text { Median }(\mathrm{Q} 1, \\
\text { Q3) }\end{array}$ & $\begin{array}{c}2800.0(-2000.0 \\
10800.0)\end{array}$ & $\begin{array}{l}600.0(-3700.0 \\
5800.0)\end{array}$ & $\begin{array}{l}10300.0(3800.0 \\
18800.0)\end{array}$ & $<0.001$ \\
\hline
\end{tabular}

* For patients with missing data, the denominator is the number of patients with valid observations. For the calculation of percentages, only valid observations are used in the numerator and denominator. $* *$ Six units of single donor platelets prepared from whole blood were pooled to produce a single pooled platelet concentrate. ${ }^{* *}$ Mixed indicates aggregate transfusions that were derived from transfusions with 2 or more different platelet products. APACHE: Acute Physiologic Assessment and Chronic Health Evaluation; CCI: corrected count increment DIC: disseminated intravascular coagulation; ICU: intensive care unit; INR: International Normalized Ratio, Q1: first quartile, Q3: third quartile.

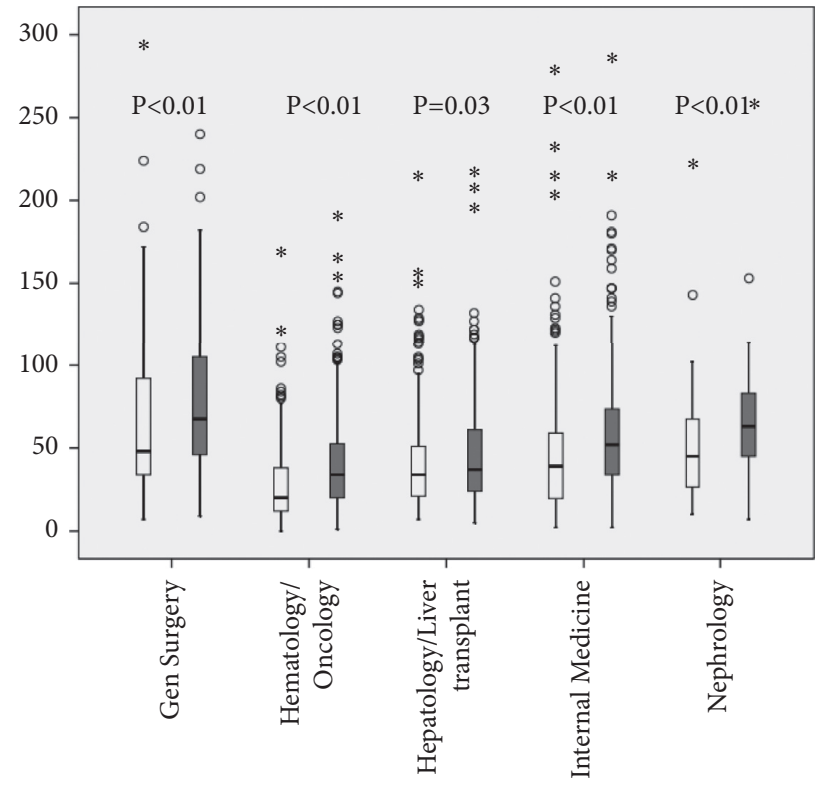

Service
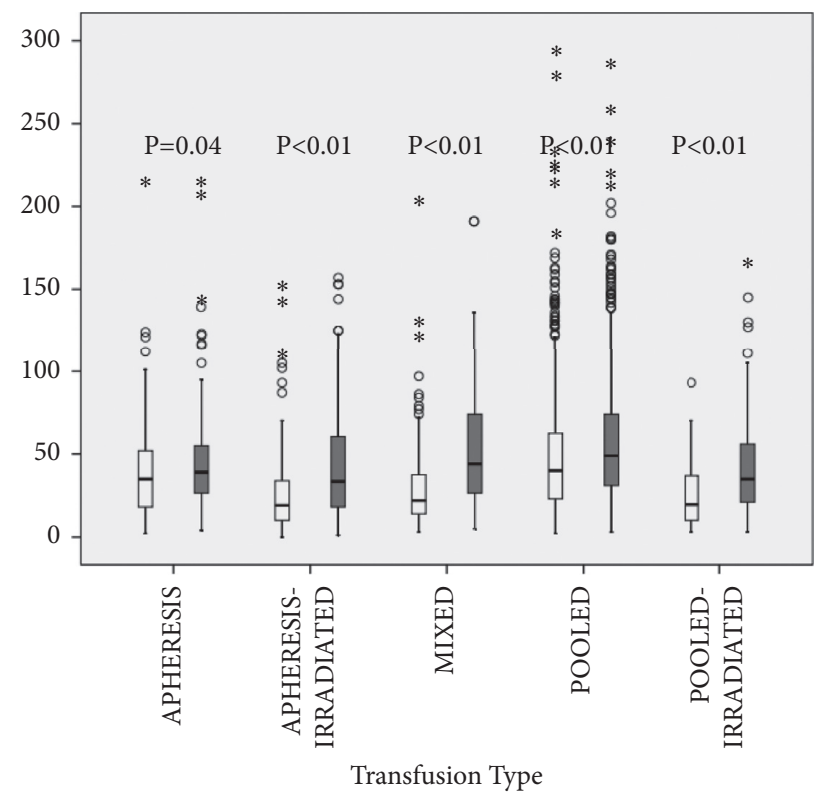

Pre-transfusion Platelet Count

Post-transfusion Platelet Count

FIGURE 1: Boxplots of platelet counts before and after platelet transfusion in patient subgroups categorized by the admitting service and by the type of platelet transfused. The platelet increment was statistically different among the different subgroups ( $p=0.04$ among the patients admitted under the different services and $p<0.01$ among the different platelet product types). Platelet counts on the $Y$-axis are in thousands $\mathrm{x} 10^{6} / \mathrm{L}$.

significant in each subgroup and among them. The median PI was the lowest in patients admitted under hepatology/ liver transplant $\left(1500.0 \times 10^{6} / \mathrm{L}\right)$ followed by those under hematology/oncology $\left(2000.0 \times 10^{6} / \mathrm{L}\right)$. The median PI was
$6500 \times 10^{6} / \mathrm{L}$ for patients under general surgery and $0.0 \times 10^{6} / \mathrm{L}$ for those under internal medicine. The median PI was $3000.0 \times 10^{6} / \mathrm{L}$ for apheresis platelets, $1000.0 \times 10^{6} / \mathrm{L}$ for apheresis-irradiated platelets, 11000.0 for pooled platelets, 
$5000.0 \times 10^{6} / \mathrm{L}$ for pooled-irradiated platelets, and $11500.0 \times 10^{6} / \mathrm{L}$ for mixed platelets.

More than half of the patients (54.8\%) had platelet transfusion refractoriness by PI $\left(<10000 \times 10^{6} / \mathrm{L}\right)$ and $57.0 \%$ by CCI $(>5000)$. There was a strong agreement between refractoriness diagnosis by PI and CCI (kappa coefficient: 0.929, 95\% CI: $0.884-0.968 ; p<0.001)$. Assuming that CCI increment was more accurate for diagnosing platelet refractoriness, diagnosis by PI had $95.2 \%$ sensitivity (95\% CI: 90.4-98.1\%) and $98.2 \%$ specificity (95\% CI: $93.6-99.8 \%)$.

Table 3 shows the prevalence of platelet refractoriness in different patient groups and platelet product types. Trauma patients were the least likely to develop refractoriness (11.1\%) compared with medical $(56.8 \%)$ and nontrauma surgical patients (53.3\%). Patients admitted under hepatology/liver transplant had the highest rates of refractoriness $(69.6 \%)$, while those under general surgery had the lowest rate $(43.2 \%)$.

The relationships between the time interval between transfusion and posttransfusion platelet count and each of PI and CCI are described in Figure 2. The Spearman r was -0.09 for both PI and CCI, indicating no significant linear correlation. As the time interval between platelet transfusion and posttransfusion platelet count was variable, we calculated the prevalence of refractoriness in the different intervals using CCI and PI definition (Table 3). When the analysis was restricted to transfusions which had platelet count measured within 3 hours, the prevalence of platelet refractoriness was $57.4 \%$ for CCI $<5000$ and $63.9 \%$ for CCI $<7500$. When it was restricted to transfusions which had posttransfusion platelet count measured after 12 hours, refractoriness was prevalent in $63.7 \%$ for CCI $<5000$ and $61.1 \%$ for CCI $<4500$.

3.3. Predictors of Platelet Transfusion Refractoriness. As shown in Table 2, the admission category, splenomegaly, chronic liver disease, and higher number of platelet transfusions were associated with platelet transfusion refractoriness on univariate analysis. Of patients with splenomegaly, $61.5 \%$ developed refractoriness compared to $46.0 \%$ of those with nonenlarged spleens $(p=0.046)$. There was a modest, but statistically significant, higher DIC likelihood score among refractory (median score: 5.0, Q1, Q3: 4.0, 6.0) compared to nonrefractory patients (median score: 5.0, Q1, Q3: 4.0, 5.0) $(p=0.04)$.

The multivariable logistic regression model showed that younger age (OR: 0.970 per year increment, 95\% CI: 0.952-0.989), nontrauma admission (OR: 11.582, 95\% CI: 1.210-110.817), and spleen size (OR: 1.174 per $\mathrm{cm}$ increment, 1.053-1.308) were associated with platelet refractoriness. The platelet product type was not associated with refractoriness. The $p$ value for the Hosmer and Lemeshow test was 0.20. The area under the curve for the receiver operating characteristic $\mathrm{C}$ statistic was 0.728 (95\% CI: 0.662-0.794). Both tests indicated that the logistic regression model was a good fit.

3.4. Factors Associated with the Time to the Next Platelet Transfusion. Several factors were associated with earlier next transfusion of platelets (Table 4). These included lower pretransfusion platelet count $(p<0.001)$ and lower PI following transfusion $(p<0.001)$. For the relationship with the type of transfused platelet concentrate, retransfusion within 2 days was least frequent with pooled platelets and most common with irradiated-pooled platelets.

3.5. Clinical Outcomes. Table 5 describes the clinical outcomes of patients. The median ICU length of stay for all patients was 13.0 days (Q1, Q3: 7.0, 23.0), and the median hospital length of stay was 28.0 days (Q1, Q3: 16.0, 58.0). ICU and hospital mortality were both high, at $59.1 \%$ and $73 \%$, respectively.

Compared to nonrefractory patients, those with platelet transfusion refractoriness had a longer stay in the ICU (median of 16.0 days compared to 12.0 days, $p=0.015$ ). However, there was no difference in either hospital or ICU mortality. Refractory patients were more likely to have a new tracheostomy tube insertion $(p=0.046)$, but with similar duration of mechanical ventilation $(p=0.15)$.

\section{Discussion}

Much of the published literature on platelet refractoriness has been described in patients with hematologic malignancies or stem cell transplantation. Table 1 summarizes selected important studies on platelet refractoriness [4-11]. In this analysis, we report on the prevalence and clinical outcome of patients with platelet transfusion refractoriness from a large cohort of critically ill patients in a large tertiarycare center.

The reported prevalence of platelet refractoriness ranged from 4.8 to $49.6 \%$ with data coming mostly from patients with hematology diseases [4-11]. We observed that $>50 \%$ of critically ill patients had evidence of platelet transfusion refractoriness. Such value exceeded most of the prior reports on the prevalence of platelet refractoriness in patients with other disorders. This was in spite of the fact that all the platelet products given at our institution were leucocyte reduced, which is well known to reduce the incidence of alloimmunization and, thus, ultimately enhance PI after transfusion [5]. The relatively high prevalence rate of platelet refractoriness in the current study could be related to the inclusion of severely ill patients in an ICU. However, it is possible that the noted prevalence herein was overestimated as the measurement of posttransfusion count was carried out after a median of five hours. However, we did not observe a clear relation between the increment in platelet count and the time interval between transfusion and measurement of posttransfusion platelet count.

$\mathrm{CCI}$ is the standard method to measure platelet recovery and survival after transfusion [24, 25]. However, it is cumbersome to use in routine clinical practice; thus, more pragmatic tools such as the PI are routinely utilized. Considering this, we compared these two tools and observed a high concordance. Such information is significant for two reasons; first, the calculation of CCI is frequently based on estimates, not actual counts, of platelet content which is subject to variation. Second, with the emergence of such data 
TABLE 3: Prevalence of platelet refractoriness based on platelet increment (PI) and different cutoffs for the corrected count index (CCI), in different patient subgroups and according to the platelet product types and the time interval between platelet transfusion and the posttransfusion platelet count.

\begin{tabular}{|c|c|c|}
\hline & \multicolumn{2}{|c|}{ Prevalence of platelet refractoriness } \\
\hline & $\mathrm{PI}<10000 \times 10^{6} / \mathrm{L}$ & CCI $<5000$ \\
\hline All patients $(N=259)$ & $54.8 \%$ & $57.0 \%$ \\
\hline \multicolumn{3}{|l|}{ Admission category } \\
\hline Medical $(N=220)$ & $56.8 \%$ & $58.5 \%$ \\
\hline Surgical $(N=30)$ & $53.3 \%$ & $60 \%$ \\
\hline Trauma $(N=9)$ & $11.1 \%$ & $11.1 \%$ \\
\hline \multicolumn{3}{|l|}{ Admitting service } \\
\hline Internal medicine $(N=74)$ & $54.5 \%$ & $56.8 \%$ \\
\hline Hematology/oncology $(N=72)$ & $58.9 \%$ & $56.9 \%$ \\
\hline Hepatology/liver transplant $(N=46)$ & $69.6 \%$ & $71.7 \%$ \\
\hline General surgery $(N=37)$ & $43.2 \%$ & $45.9 \%$ \\
\hline Splenomegaly $^{*}(N=65)$ & $61.5 \%$ & $64.6 \%$ \\
\hline No splenomegaly $(N=113)$ & $46.0 \%$ & $50 \%$ \\
\hline \multicolumn{3}{|l|}{ Platelet product type } \\
\hline Apheresis $\left(N=139^{* *}\right)$ & $62.6 \%$ & $64 \%$ \\
\hline Apheresis-irradiated $\left(N=195^{* *}\right)$ & $46.9 \%$ & $47.7 \%$ \\
\hline Pooled $\left(N=747^{* *}\right)$ & $59.1 \%$ & $61.6 \%$ \\
\hline Pooled-irradiated $\left(N=179^{* *}\right)$ & $47.3 \%$ & $50.3 \%$ \\
\hline Mixed $^{* * *}\left(N=90^{* *}\right)$ & $48.4 \%$ & $65.6 \%$ \\
\hline \multicolumn{3}{|c|}{ Time interval between platelet transfusion and the posttransfusion platelet count } \\
\hline$<3$ hours $\left(N=319^{* *}\right)$ & $55.4 \%$ & $57.4 \%(63.9 \%$ for $\mathrm{CCI}<7500)$ \\
\hline $3-6$ hours $\left(N=583^{* *}\right)$ & $51.3 \%$ & $55.2 \%$ \\
\hline $7-12$ hours $\left(N=292^{* *}\right)$ & $61.0 \%$ & $63.4 \%$ \\
\hline$>12$ hours $\left(N=113^{* *}\right)$ & $60.3 \%$ & $63.7 \%(61.1 \%$ for $\mathrm{CCI}<4500)$ \\
\hline
\end{tabular}

${ }^{*}$ Spleen size was known in 178 patients. For the calculation of percentages, only valid observations are used in the numerator and denominator. ${ }^{* *}$ Transfusion episodes. ${ }^{* * *}$ Mixed indicates aggregate transfusions that were derived from transfusions with 2 or more different platelet products.
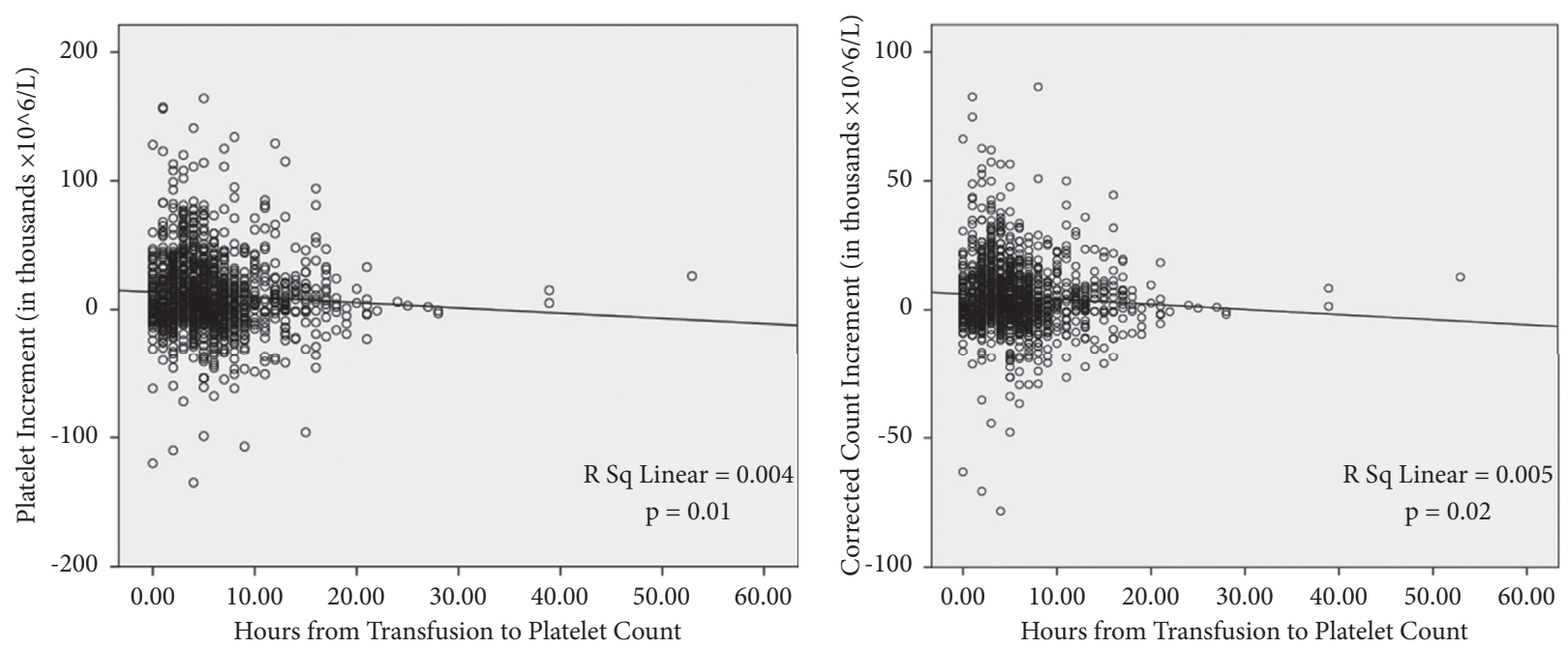

FIGURE 2: The relationship between the time interval between platelet transfusion and the posttransfusion platelet count and each of the platelet increment (PI) and corrected count increment (CCI). The Spearman $r$ was -0.09 for both PI and CCI.

showing equivalence among the two methods, clinicians would likely opt to use the more practical PI calculation [26].

Several factors may impact posttransfusion increment in platelet count. In this study, platelet refractoriness was more prevalent in patients admitted under hepatology/liver transplant services. On multivariable logistic regression analysis, we also found that younger age, medical or surgical admission versus trauma, and larger spleen size were associated with higher risk of platelet refractoriness. Other factors that were not studied may be important. These included platelet source and manipulation, ABO matching, and duration of storage in the blood bank [27]. Being a large tertiary-care and trauma center, the platelet storage time in the current study is expected to be short. Furthermore, most platelet products were from pooled platelets, rendering the platelet source and content to be more homogenous. 
TABLE 4: Characteristics of platelet transfusions by the time to the next transfusion.

\begin{tabular}{|c|c|c|c|c|c|}
\hline & & Total $(N=1118)$ & $\begin{array}{l}\text { Less than } 2 \text { days } \\
\quad(N=643)\end{array}$ & $\begin{array}{c}2 \text { days or more } \\
(N=475)\end{array}$ & $p$ value \\
\hline $\begin{array}{l}\text { Platelet count prior to transfusion } \\
\left(\times 10^{6} / \mathrm{L}\right)\end{array}$ & $\begin{array}{l}\text { Median } \\
(\mathrm{Q} 1, \mathrm{Q} 3)\end{array}$ & $\begin{array}{l}31000.0(16000.0 \\
50000.0)\end{array}$ & $\begin{array}{l}28000.0(14000.0, \\
45000.0)\end{array}$ & $\begin{array}{l}37000.0(19000.0 \\
58000.0)\end{array}$ & $<0.001$ \\
\hline $\begin{array}{l}\text { Number of platelet concentrates per } \\
\text { transfusion episode }\end{array}$ & $\begin{array}{l}\text { Median } \\
(\mathrm{Q} 1, \mathrm{Q} 3)\end{array}$ & $1.0(1.0,2.0)$ & $1.0(1.0,2.0)$ & $1.0(1.0,1.0)$ & 0.04 \\
\hline Platelet increment $\left(\mathrm{x}^{6} 0^{6} / \mathrm{L}\right)$ & (Q1, Q3) & $\begin{array}{c}6000.0(-5000.0 \\
24000.0)\end{array}$ & $\begin{array}{c}5000.0(-6000.0 \\
19000.0)\end{array}$ & $\begin{array}{c}9000.0(-4000.0 \\
29000.0)\end{array}$ & $<0.001$ \\
\hline Platelet product type & $\mathrm{N}\left(\%^{* *}\right)$ & & & & \\
\hline Apheresis & & 111 & $71(64.0)$ & $40(36.0)$ & 0.16 \\
\hline Apheresis-irradiated & & 163 & $101(62.0)$ & $62(38.0)$ & 0.23 \\
\hline Pooled & & 608 & $310(51.0)$ & $298(49.0)$ & $<0.001$ \\
\hline Pooled-irradiated & & 157 & $109(69.4)$ & $48(30.6)$ & 0.001 \\
\hline Mixed*** & & 79 & $52(65.8)$ & $27(34.2)$ & 0.13 \\
\hline $\begin{array}{l}\text { Time to the next platelet transfusion } \\
\text { (days) }\end{array}$ & $\begin{array}{l}\text { Median (Q1, } \\
\text { Q3) }\end{array}$ & $1.0(1.0,2.0)$ & $1.0(1.0,1.0)$ & $3.0(2.0,4.0)$ & $<0.001$ \\
\hline
\end{tabular}

*Six units of single donor platelets prepared from whole blood were pooled to produce a single pooled platelet concentrate. ${ }^{* *}$ The denominator is the total number of transfusion episodes of the platelet product type. ${ }^{* * *}$ Mixed indicates aggregate transfusions that were derived from transfusions with 2 or more different platelet products. Q1: first quartile, Q3: third quartile.

TABle 5: Outcomes of patients by platelet refractory status based on the platelet increment $\left(<10000 \times 10^{6} / \mathrm{L}\right)$ definition.

\begin{tabular}{|c|c|c|c|c|c|}
\hline & & Total $(N=259)$ & Yes $(N=142)$ & No $(N=117)$ & $p$ value \\
\hline ICU mortality & $N(\%)$ & $153(59.1)$ & $86(60.6)$ & $67(57.3)$ & 0.55 \\
\hline Hospital mortality & $N(\%)$ & $189(73.0)$ & $105(73.9)$ & $84(71.8)$ & 0.70 \\
\hline New tracheostomy/238 patients ${ }^{*}$ & $N(\%)$ & $25(10.9)$ & $19(14.4)$ & $6(6.1)$ & 0.046 \\
\hline $\begin{array}{l}\text { Duration of mechanical ventilation (days)/238 } \\
\text { patients }\end{array}$ & Median (Q1, Q3) & $10.0(6.0,17.0)$ & $10.0(5.0,15.8)$ & $12.0(6.0,19.5)$ & 0.15 \\
\hline ICU length of stay (days) & Median (Q1, Q3) & $13.0(7.0,23.0)$ & $16.0(8.0,26.0)$ & $12.0(6.0,21.0)$ & 0.02 \\
\hline Hospital length of stay (days) & Median (Q1, Q3) & $28.0(16.0,58.0)$ & $33.0(16.0,62.5)$ & $27.0(14.0,47.0)$ & 0.11 \\
\hline
\end{tabular}

${ }^{*}$ For patients with missing data, the denominator is the number of patients with valid observations. For the calculation of percentages, only valid observations are used in the numerator and denominator. ICU: intensive care unit, Q1: first quartile, Q3: third quartile.

Refractoriness to platelet transfusions has been associated with adverse clinical outcomes including prolonged hospital stay and increased risk of bleeding as well as mortality (Table 1) $[6,8,11,15]$. We found that patients with platelet transfusion refractoriness had high mortality, but it was similar to that of patients who did not have refractoriness. Prior data in patients with hematologic malignancies reported that early and late deaths were more common in the refractory group (Table 1), predominantly due to fatal hemorrhage [11]. We speculate that the differences in findings could be due to the increased incidence of immune causes of refractoriness in patients with hematologic malignancies. Such alloimmunization renders the patient more refractory and ultimately at increased risk for severe bleeding episodes.

This analysis carries multiple limitations that emanate mainly from the retrospective single-center study design. The measurement of platelet count after transfusion was carried out at different time intervals. Ideally, it should be carried out within an hour after transfusion to offset any pooling of platelets that subsequently occurs in the spleen. For the calculation of CCI, we used an estimate of platelet content in each of the transfused units and used a CCI cutoff of 5000 to define platelet refractoriness $[5,9,10]$. Other cutoffs have been used such as $<7500$ at 1 hour and $<4500$ at 24 hours [8]. Additionally, we did not have data about the immunization of patients against platelet surface antigens. These factors affect the interpretation of the current study and comparing our results with those of others. A number of important points should be highlighted. First, to our knowledge, this is the first analysis of platelet refractoriness in the critical care setting and sheds some insight on its prevalence and outcome in such patients. Second, we used two methods to estimate platelet refractoriness and demonstrated that they were concordant. Nevertheless, this study should be considered as pilot and our findings require further validation in large prospective studies.

\section{Conclusions}

In conclusion, critically ill patients receiving at least two transfusions of platelets had high $(>50 \%)$ prevalence of platelet transfusion refractoriness, defined by $\mathrm{PI}<10000 \times 10^{6} / \mathrm{L}$ and $\mathrm{CCI}<5000$. Younger age, nontrauma admissions, and larger spleen size were associated with higher risk of platelet refractoriness. The mortality rate of our patients was high, but platelet transfusion refractoriness was not associated with increased mortality. 


$\begin{array}{ll}\text { Abbreviations } \\ \text { APACHE: } & \text { Acute Physiologic Assessment and Chronic } \\ & \text { Health Evaluation } \\ \text { CCI: } & \text { Corrected count increment } \\ \text { CI: } & \text { Confidence interval } \\ \text { DIC: } & \text { Disseminated intravascular coagulation } \\ \text { ICU: } & \text { Intensive care unit } \\ \text { OR: } & \text { Odds ratio } \\ \text { PI: } & \text { Platelet increment } \\ \text { Q: } & \text { Quartile. }\end{array}$

\section{Data Availability}

The datasets used and/or analyzed during the current study are available from the corresponding author on reasonable request.

\section{Ethical Approval}

This study was approved by the Institution Review Board of the Ministry of National Guard Health Affairs, Riyadh, Saudi Arabia.

\section{Disclosure}

This study was presented in part at the 2020 Congress of the Society of Critical Care Medicine. The manuscript was presented as a preprint at Research Square (http://www. researchsquare.com/article/rs-52220/v1).

\section{Conflicts of Interest}

All authors declare no conflicts of interest.

\section{Authors' Contributions}

SA, AOA. AA, and HMD conceptualized and designed the work; SA and AOA. AA acquired data. SA, EM, and HMD analysed the data. SA, AOA. AA, EM, MD, and HMD interpreted the data and revised and critically reviewed the manuscript. SA, AOA. AA, MD, and HMD prepared the manuscript draft. All authors read and approved the final manuscript.

\section{Acknowledgments}

The authors would like to acknowledge Ms. Haya Al Wasel and the rest of the King Abdulaziz Medical City blood bank staff, as well as Dr. Mohammad Arabi from Vascular and Interventional Radiology, for their great assistance in the data collection for this study.

\section{References}

[1] P. Hui, D. J. Cook, W. Lim, G. A. Fraser, and D. M. Arnold, "The frequency and clinical significance of thrombocytopenia complicating critical illness," Chest, vol. 139, no. 2, pp. 271-278, 2011.

[2] D. R. Williamson, M. Albert, D. Heels-Ansdell et al., "Thrombocytopenia in critically ill patients receiving thromboprophylaxis," Chest, vol. 144, no. 4, pp. 1207-1215, 2013.

[3] P. Rebulla, "Refractoriness to platelet transfusion," Current Opinion in Hematology, vol. 9, no. 6, pp. 516-520, 2002.

[4] T. J. Legler, I. Fischer, J. Dittmann et al., "Frequency and causes of refractoriness in multiply transfused patients," Annals of Hematology, vol. 74, no. 4, pp. 185-189, 1997.

[5] Trial to Reduce Alloimmunization to Platelets Study, "G. Leukocyte reduction and ultraviolet B irradiation of platelets to prevent alloimmunization and refractoriness to platelet transfusions," New England Journal of Medicine, vol. 337, no. 26, pp. 1861-1869, 1997.

[6] K. R. Meehan, C. O. Matias, S. S. Rathore et al., "Platelet transfusions: utilization and associated costs in a tertiary care hospital," American Journal of Hematology, vol. 64, no. 4, pp. 251-256, 2000.

[7] S. J. Slichter, K. Davis, and H. Enright, "Factors affecting posttransfusion platelet increments, platelet refractoriness, and platelet transfusion intervals in thrombocytopenic patients," Blood, vol. 105, no. 10, pp. 4106-4114, 2005.

[8] J.-L. H. Kerkhoffs, J. C. J. Eikenboom, L. M. G. van de Watering, R. J. van Wordragen-Vlaswinkel, P. W. Wijermans, and A. Brand, "The clinical impact of platelet refractoriness: correlation with bleeding and survival," Transfusion, vol. 48, no. 9, pp. 1959-1965, 2008.

[9] A. A. Ferreira, R. Zulli, S. Soares, V. d. Castro, and H. MoraesSouza, "Identification of platelet refractoriness in oncohematologic patients," Clinics, vol. 66, no. 1, pp. 35-40, 2011.

[10] J. R. Hess, F. L. Trachtenberg, S. F. Assmann et al., "Clinical and laboratory correlates of platelet alloimmunization and refractoriness in the PLADO trial," Vox Sanguinis, vol. 111, no. 3, pp. 281-291, 2016.

[11] T. Comont, S. Tavitian, L. Bardiaux et al., "Platelet transfusion refractoriness in patients with acute myeloid leukemia treated by intensive chemotherapy," Leukemia Research, vol. 61, pp. 62-67, 2017.

[12] H.-G. Klingemann, S. Self, M. Banaji et al., "Refractoriness to random donor platelet transfusions in patients with aplastic anaemia: a multivariate analysis of data from 264 cases," British Journal of Haematology, vol. 66, no. 1, pp. 115-121, 1987.

[13] E. Hod and J. Schwartz, "Platelet transfusion refractoriness," British Journal of Haematology, vol. 142, no. 3, pp. 348-360, 2008.

[14] G. J. Laundy, B. A. Bradley, B. M. Rees, M. Younie, and J. M. Hows, "Incidence and specificity of HLA antibodies in multitransfused patients with acquired aplastic anemia," Transfusion, vol. 44, no. 6, pp. 814-825, 2004.

[15] A. Toor, S. Choo, and J. Little, "Bleeding risk and platelet transfusion refractoriness in patients with acute myelogenous leukemia who undergo autologous stem cell transplantation," Bone Marrow Transplantation, vol. 26, no. 3, pp. 315-320, 2000.

[16] M. W. N. Nijsten, H.-J. ten Duis, J. G. Zijlstra et al., "Blunted rise in platelet count in critically ill patients is associated with worse outcome," Critical Care Medicine, vol. 28, no. 12, pp. 3843-3846, 2000.

[17] Y. Arabi, A. Alshimemeri, and S. Taher, "Weekend and weeknight admissions have the same outcome of weekday admissions to an intensive care unit with onsite intensivist coverage*," Critical Care Medicine, vol. 34, no. 3, pp. 605-611, 2006.

[18] R. M. Kaufman, B. Djulbegovic, T. Gernsheimer et al., "Platelet transfusion: a clinical practice guideline from the AABB," Annals of Internal Medicine, vol. 162, no. 3, pp. 205-213, 2015. 
[19] T. Kouno, N. Katsumata, H. Mukai, M. Ando, and T. Watanabe, "Standardization of the body surface area (BSA) formula to calculate the dose of anticancer agents in Japan," Japanese Journal of Clinical Oncology, vol. 33, no. 6, pp. 309-313, 2003.

[20] A. L. Pozo, E. M. Godfrey, and K. M. Bowles, "Splenomegaly: investigation, diagnosis and management," Blood Reviews, vol. 23, no. 3, pp. 105-111, 2009.

[21] M. A. Crowther, D. J. Cook, M. O. Meade et al., "Thrombocytopenia in medical-surgical critically ill patients: prevalence, incidence, and risk factors," Journal of Critical Care, vol. 20, no. 4, pp. 348-353, 2005.

[22] T. Iba, J. H. Levy, A. Raj, and T. E. Warkentin, "Advance in the management of sepsis-induced coagulopathy and disseminated intravascular coagulation," Journal of Clinical Medicine, vol. 8, no. 5, 2019.

[23] Z. Bursac, C. H. Gauss, D. K. Williams, and D. W. Hosmer, "Purposeful selection of variables in logistic regression," Source Code for Biology and Medicine, vol. 3, no. 1, pp. 17-18, 2008.

[24] T. O. Apelseth, Ø. Bruserud, T. Wentzel-Larsen, and T. Hervig, "Therapeutic efficacy of platelet transfusion in patients with acute leukemia: an evaluation of methods," Transfusion, vol. 50, no. 4, pp. 766-775, 2010.

[25] M. Karafin, A. K. Fuller, W. J. Savage, K. E. King, P. M. Ness, and A. A. R. Tobian, "The impact of apheresis platelet manipulation on corrected count increment," Transfusion, vol. 52, no. 6, pp. 1221-1227, 2012.

[26] J. C. Jaime-Perez, K. E. Vazquez-Hernandez, R. A. JimenezCastillo, L. T. Fernandez, R. Salazar-Riojas, and D. GomezAlmaguer, "Platelet survival in hematology patients assessed by the corrected count increment and other formulas," American Journal of Clinical Pathology, vol. 150, no. 3, pp. 267-272, 2018.

[27] D. J. Triulzi, S. F. Assmann, R. G. Strauss et al., "The impact of platelet transfusion characteristics on posttransfusion platelet increments and clinical bleeding in patients with hypoproliferative thrombocytopenia," Blood, vol. 119, no. 23, pp. 5553-5562, 2012. 